\title{
Assessment of the Effects of Cinnamon Leaf Oil on Rumen Microbial Fermentation Using Two Continuous Culture Systems ${ }^{1}$
}

\author{
G. R. Fraser, ${ }^{\star} †$ A. V. Chaves, $\ddagger$ Y. Wang, $\ddagger$ T. A. McAllister, $\ddagger$ K. A. Beauchemin, $\ddagger$ and C. Benchaar ${ }^{2}$ \\ *Nova Scotia Agricultural College, Truro, Nova Scotia, Canada B2N 5E3 \\ †Agriculture and Agri-Food Canada, Dairy and Swine Research and Development Centre, Sherbrooke, Quebec, Canada J1M 1 Z3 \\ $\ddagger$ Agriculture and Agri-Food Canada, Lethbridge, Alberta, Canada T1J 4B1
}

\begin{abstract}
Two continuous culture (CC) systems, the rumen simulation technique (Rusitec) and a dual-flow (DF) fermenter, were used to evaluate effects of the essential oil from cinnamon leaf (CIN) on rumen microbial fermentation. Incubations (d 1 through 8 for adaptation and d 9 through 16 for sampling) were conducted concurrently in the 2 systems, with CIN added at 0 (control) and 500 $\mathrm{mg} / \mathrm{L}$ of rumen fluid culture. Eight Rusitec $(920 \mathrm{~mL}$; dilution rate $=2.9 \% / \mathrm{h})$ and $6 \mathrm{DF}(1,300 \mathrm{~mL}$; dilution rate $=6.3 \% / \mathrm{h}$ ) fermenters were randomly assigned to treatment. Inoculum was prepared from 4 ruminally cannulated lactating Holstein cows fed a total mixed ration consisting of $51 \%$ forage and $49 \%$ concentrate (dry matter basis). Ruminal $\mathrm{pH}$, total volatile fatty acid (VFA) concentration, and diet digestibility were reduced by CIN addition in the Rusitec but were not affected by CIN administration in the DF. The addition of CIN in the Rusitec decreased apparent $\mathrm{N}$ disappearance, $\mathrm{NH}_{3}$ $\mathrm{N}$ concentration, and molar proportions of branchedchain VFA. In contrast, in the DF no effect of CIN was observed on apparent $\mathrm{N}$ degradation, $\mathrm{NH}_{3}-\mathrm{N}$ concentration, and molar proportion of branched-chain VFA. In the Rusitec, the molar proportion of acetate was similar between treatments on d 9 and 13, but was lower from d 10 to 12 and higher on d 14 to 16 with CIN than with control (interaction of treatment $\times$ sampling day). The molar proportion of acetate remained unaffected by CIN addition in the DF. In both CC systems, the molar proportion of propionate was decreased whereas that of butyrate was increased by CIN addition. In the DF, CIN decreased microbial $\mathrm{N}$ flow and efficiency of microbial protein synthesis. Protozoa numbers were lower with CIN than with control in both CC fermenters. In the
\end{abstract}

\footnotetext{
Received October 18, 2006.

Accepted December 11, 2006.

${ }^{1}$ Contribution number 908 from the Dairy and Swine Research and Development Centre, P.O. Box 90, STN-Lennoxville, Sherbrooke, Canada J1M $1 Z 3$.

${ }^{2}$ Corresponding author: benchaarc@agr.gc.ca
}

Rusitec, CIN increased ${ }^{15} \mathrm{~N}$ enrichment in total bacterial fractions, but no effect was observed on the production of microbial N. This study showed that CIN exhibited antimicrobial activity in both CC systems, but the effects were more pronounced in the Rusitec than in the DF system. These differences are likely a reflection of the higher dilution rate in the DF resulting in a lower effective concentration of CIN than in Rusitec. Based on these changes in rumen microbial fermentation, supplementation of CIN at the concentration evaluated in this study may not be nutritionally beneficial to ruminants.

Key words: cinnamon leaf oil, rumen microbial fermentation, rumen simulation technique, dual-flow fermenter

\section{INTRODUCTION}

With increasing public concern that the routine use of antibiotics and growth promoters in livestock feeds may heighten bacterial resistance to antibiotics, interest in evaluating plant extracts, and more recently essential oils (EO), as natural alternatives to antibiotics has arisen (Greathead, 2003). Contrary to what their name might suggest, essential oils are not oils (i.e., lipids) because they consist solely of volatile, aromatic compounds that can be extracted from plants mainly by steam distillation. Structurally, they are variable mixtures of principally terpenoids-mainly monoterpenes $\left(\mathrm{C}_{10}\right)$ and sesquiterpenes $\left(\mathrm{C}_{15}\right)$, although diterpenes $\left(\mathrm{C}_{20}\right)$ may also be present-and a variety of low molecular weight aliphatic hydrocarbons, acids, alcohols, aldehydes, acyclic esters or lactones, and sometimes $\mathrm{N}$ - and S-containing compounds, coumarins, and homologues of phenylpropanoids (Dorman and Deans, 2000). Essential oils have been shown to have antimicrobial activity against a variety of microorganisms, including grampositive and gram-negative bacteria, protozoa, and fungi (Helander et al., 1998; Greathead, 2003). The mechanism by which EO are thought to exert their antimicrobial activity is by disrupting the cell wall structures, affecting electron transport, ion gradients, protein translocation, phosphorylation steps, and other enzyme-dependent reactions (Ultee et al., 1999; Dorman and Deans, 2000). 
A number of recent in vitro studies using batch or continuous cultures have evaluated effects of various EO and their compounds on ruminal microorganisms and ruminal metabolism and have reported varied results (Busquet et al., 2006; Castillejos et al., 2006). Inconsistencies among studies may be attributed to factors such as the chemical composition of the EO, the concentration used, and interactions among the bioactive agents in EO (Dorman and Deans, 2000). The in vitro technique used may also influence results. For instance, Busquet et al. (2005a) showed that garlic oil and 2 of its compounds, diallyl disulfide and allyl mercaptan (300 $\mathrm{mg} / \mathrm{L}$ of rumen fluid), reduced total VFA concentration in a 24-h batch culture. When evaluated at the same concentration in a continuous culture $(\mathbf{C C})$ system under controlled $\mathrm{pH}$ conditions, allyl mercaptan reduced total VFA concentration but no effect was observed for garlic oil and diallyl disulfide.

In vitro batch culture studies must be interpreted with caution because they report effects over a set incubation time ( 24 or $48 \mathrm{~h}$ ) and do not account for the possible adaptation of rumen microbes to EO compounds. Conversely, $\mathrm{CC}$ systems are advantageous in that they allow for longer term effects, but there is no standardization among systems. Discrepancies among studies using different CC systems may be attributed to the type of system used, dilution rate, and ruminal bacterial activity (Vázquez-Añón et al., 2001).

Accordingly, the objective of this study was to use 2 CC systems: the rumen simulation technique (Rusitec; Czerkawski and Breckenridge, 1977) and a dual-flow (DF) fermenter (Hoover et al., 1976), to examine the effects of cinnamon leaf oil (CIN) on rumen microbial fermentation.

\section{MATERIALS AND METHODS}

\section{Experimental Design and Treatments}

The experiment was designed as a complete randomized block with 2 dietary treatments and replication within each treatment (4 replications in the Rusitec system and 3 replications in the DF system). The experimental period consisted of $16 \mathrm{~d}$, whereby the first $8 \mathrm{~d}$ (d 1 to 8) served as an adaptation period to allow for equilibration of microbial populations, followed by $8 \mathrm{~d}$ of sampling ( 9 to 16). The 2 experimental treatments were 1) control (CON, no additive), and 2) addition of CIN (Cinnamomum zeylanicum; standardized at $76 \mathrm{~g} /$ $\mathrm{kg}$ of eugenol; Pancosma S. A., Bellegarde-sur-Valserine, France) at a concentration of $500 \mathrm{mg} / \mathrm{L}$ of culture ruminal fluid. The concentration of $500 \mathrm{mg} / \mathrm{L}$ was selected based on a previous batch-culture screening study conducted in our laboratory (unpublished data), which revealed that $500 \mathrm{mg} / \mathrm{L}$ of CIN was the threshold beyond
Table 1. Chemical composition of the barley silage and the concentrate feed administered to the continuous culture fermenters

\begin{tabular}{lcc}
\hline Item & $\begin{array}{c}\text { Barley } \\
\text { silage }\end{array}$ & Concentrate \\
\hline $\mathrm{DM}, \%$ & 32.5 & 93.6 \\
OM, \% of DM & 92.7 & 89.9 \\
CP, \% of DM & 12.0 & 23.9 \\
NDF, \% of DM & 49.2 & 24.5 \\
ADF, \% of DM & 30.7 & 8.71 \\
Starch, \% of DM & 35.0 & 64.2 \\
Ether extract, \% of DM & 2.20 & 2.70 \\
Gross energy, Mcal/kg of DM & $4,042.3$ & $4,112.1$ \\
\hline
\end{tabular}

which changes in the fermentation pattern were observed.

\section{Source of Inoculum}

Rumen inoculum was obtained $2 \mathrm{~h}$ after the morning feeding from 4 ruminally fistulated, lactating Holstein dairy cows fed a TMR $(16.7 \% \mathrm{CP}, 34.4 \% \mathrm{NDF})$ consisting of whole-crop barley silage (46.6\%), alfalfa hay (4.5\%), dry ground corn $(6.8 \%)$, steam-rolled barley (17.6\%), pelleted dairy supplement (23.3\%), and canola oil (1.2\%). The pellets contained (DM basis) ground barley grain (14.1\%), ground corn grain $(0.05 \%)$, heat-processed canola meal (20.8\%), beet pulp (11.9\%), heat-treated soybean meal (20.6\%), corn gluten meal (17.0\%), dry molasses $(6.5 \%)$, limestone $(1.7 \%)$, dicalcium phosphate $(2.7 \%)$, sodium bicarbonate (1.6\%), and a salt, mineral, and vitamin mixture $(2.7 \%)$. Pooled rumen fluid inoculum for use in the Rusitec was squeezed through 4 layers of cheesecloth into an insulated thermos. A small amount (approximately $160 \mathrm{~g}$ ) of solid rumen content was also collected for initial inoculation of the fermenters. Mixed ruminal contents for use in the DF were pooled and homogenized for 1 min using a Waring commercial blender (Waring Products Division, New Hartford, CT) under a stream of $\mathrm{CO}_{2}$ to detach feed particleassociated (FPA) bacteria. The homogenized material was then squeezed through 2 layers of cheesecloth into an insulated thermos. All procedures with the cows were performed in accordance with the guidelines of the Canadian Council on Animal Care (CCAC, 1993).

\section{Diet Substrate}

Whole-crop barley silage and a concentrate mix fed to dairy cows were used as dietary substrates (Table 1 ). The barley silage was sampled at various locations within a bunker silo and samples were immediately stored at $-20^{\circ} \mathrm{C}$. Just prior to the beginning of the experiment, feedstuffs were freeze-dried and ground through a 4.5mm screen (Arthur H. Thomas Co., Philadelphia, PA). 
In the Rusitec system, equal quantities of barley silage and concentrate were incubated in separate polyester bags $(80 \times 120 \mathrm{~mm}$; pore size of $50 \mu \mathrm{m}$; B. \& S.H. Thompson, Ville Mont-Royal, QC, Canada). In the DF system, equal quantities of barley silage and concentrate (50:50, DM basis) were hand-mixed to obtain a TMR and incubated as free-floating particles in the fermenters.

\section{Experimental Apparatuses and Operation}

Rusitec. A Rusitec unit (Czerkawski and Breckenridge, 1977) equipped with 8 fermenters each of $920-\mathrm{mL}$ nominal capacity was used in this study. To begin the experiment, each fermentation vessel $(\mathrm{n}=8)$ was filled with $200 \mathrm{~mL}$ of warmed McDougall's buffer ( $\mathrm{pH} 8.2$; McDougall, 1948) modified to contain $1.0 \mathrm{~g} / \mathrm{L}$ of $\left(\mathrm{NH}_{4}\right)_{2} \mathrm{SO}_{4}$, and $700 \mathrm{~mL}$ of filtered rumen fluid. In addition, solid rumen digesta ( $20 \mathrm{~g})$, barley silage ( $5 \mathrm{~g}, \mathrm{DM}$ basis), and concentrate ( $5 \mathrm{~g}, \mathrm{DM}$ basis) contained in 3 separate polyester bags were placed within each fermentation vessel. After $24 \mathrm{~h}$, the solid rumen digesta bag was replaced with 2 polyester bags containing either 5 $\mathrm{g}$ of barley silage or concentrate. Thereafter, 2 nylon bags (one of concentrate and the other of barley silage) were replaced daily, allowing each bag to remain in the fermenter for $48 \mathrm{~h}$. Artificial saliva was continuously infused into the fermenters at a dilution rate of $2.9 \% / \mathrm{h}$. During nylon bag exchange, each fermentation vessel was flushed with $\mathrm{O}_{2}$-free $\mathrm{CO}_{2}$ to maintain anaerobic conditions. Effluent accumulation was determined daily during feed-bag exchange and collected in a $2.0-\mathrm{L}$ container immersed in an ice water bath to impede microbial growth. Beginning on d 9, CIN (500 mg/L of culture ruminal fluid) was administered once daily to each of the 4 treatment fermenters. The daily dose of CIN was deposited directly into the fermentation fluid at the time of morning feeding.

DF Fermenter. A 6-unit, dual-effluent system similar to that described by Hoover et al. (1976) was used concurrently with the Rusitec in this study. Each fermentation unit had a 1.3-L nominal capacity. To begin, $275 \mathrm{~mL}$ of warmed McDougall's buffer ( $\mathrm{pH} 8.2 ; \mathrm{McDougall}, 1948$ ) modified to contain $1.0 \mathrm{~g} / \mathrm{L}$ of $\left(\mathrm{NH}_{4}\right)_{2} \mathrm{SO}_{4}, 1,000 \mathrm{~mL}$ of strained rumen fluid, and $15 \mathrm{~g}$ of TMR (DM basis) were added to each fermenter. Thereafter, the fermenters were manually given $30 \mathrm{~g}$ (DM basis) of diet per day, divided into 2 equal feedings. Fermenters were maintained at a constant temperature of $39^{\circ} \mathrm{C}$ and were infused with a constant stream of $\mathrm{N}_{2}$ at a rate of $20 \mathrm{~mL} / \mathrm{min}$ to maintain anaerobic conditions. Infusion of artificial saliva and flow of filtered liquid were set to maintain solid and liquid dilution rates of approximately 2.0 and $4.3 \% / \mathrm{h}$, respectively. Daily effluent was collected in a 4.0-L container immersed in an ice water bath to inhibit microbial growth. Beginning on d 9, CIN (500 mg/L of culture ruminal fluid) was administered once daily to each of the 3 treatment fermenters. The daily dose of CIN was deposited directly into the fermentation fluid at the time of morning feeding.

\section{Sample Collection: Rusitec Apparatus}

DM Disappearance. In situ DM disappearance at $48 \mathrm{~h}$ was determined daily from d 9 to 16 . Feed bags were removed from each fermenter, washed in cold, running tap water until the water running off was clear, and dried at $55^{\circ} \mathrm{C}$ for $48 \mathrm{~h}$. To ensure there was sufficient sample for analysis, silage and concentrate bag residues were pooled over 2 and $3 \mathrm{~d}$, respectively, ground through a 1-mm screen in a Wiley mill (standard model 4; Arthur $\mathrm{H}$. Thomas) and subsequently analyzed for NDF, ADF, and total N.

Fermentation Gas and End-Products. Fermentation gas was collected into reusable 2,000-mL, vinyl urine collection bags (Bard Inc., Mississauga, ON, Canada) attached to each fermenter. Just prior to feed-bag exchange, daily total gas production from each fermenter was determined using a wet-type gas flow meter (Alexander-Wright, London, UK). From d 9 to 16, just prior to determination of total gas, gas samples were taken from the septum of collection bags using a 26gauge needle (Becton Dickinson, Franklin Lakes, NJ). Twenty-milliliter samples were transferred to evacuated 6.8-mL exetainers (Labco Ltd., Wycombe, Bucks, UK) for immediate analysis of methane $\left(\mathrm{CH}_{4}\right)$ concentration. Fermenter pH was recorded (Orion model 260A, Fisher Scientific, Toronto, ON, Canada) daily at the time of feed-bag exchange. To determine VFA concentration, 4.0-mL subsamples of fermenter liquid taken directly from the fermentation vessels at the time of feed-bag exchange were placed in screw-capped vials preserved with $400 \mu \mathrm{L}$ of $25 \%$ (wt/wt) metaphosphoric acid and immediately frozen at $-20^{\circ} \mathrm{C}$ until analysis. At the same time, 4.0-mL subsamples of fermenter fluid were also collected, placed in screw-capped vials, preserved with $400 \mu \mathrm{L}$ of TCA, and immediately frozen at $-20^{\circ} \mathrm{C}$ until analyzed for $\mathrm{NH}_{3}-\mathrm{N}$ concentration.

Protozoa Enumeration. Protozoa counts were determined daily on pooled fluid samples collected from both the 48-h barley silage and concentrate feed bags from each fermenter. Bags were gently pressed to expel fermentation fluid and a 5.0-mL subsample of rumen fluid was obtained and preserved using $5.0 \mathrm{~mL}$ of methyl green formalin-saline solution (Ogimoto and Imai, 1981). Protozoa samples were stored in darkness at room temperature until counting. Protozoa were enumerated microscopically in a Levy-Hausser counting chamber (Hausser Scientific, Horsham, PA). Each sample was 
counted twice and if the average of the duplicates differed by more than $10 \%$, counts were repeated.

Microbial Protein Synthesis. Bacteria in the fermenters were labeled using ${ }^{15} \mathrm{~N}$. On d 8, McDougall's buffer (McDougall, 1948) was modified by replacing the $\left(\mathrm{NH}_{4}\right)_{2} \mathrm{SO}_{4}$ with $1.0 \mathrm{~g} / \mathrm{L}$ of ${ }^{15} \mathrm{~N}$-enriched $\left(\mathrm{NH}_{4}\right)_{2} \mathrm{SO}_{4}$ (Sigma Chemical Co., St. Louis, MO; minimum ${ }^{15} \mathrm{~N}$ enrichment 10.01 atom\%) until the end of the experiment. On d 15 and16, effluent samples $(250 \mathrm{~mL})$ preserved on ice were collected from the effluent container to obtain a sample of liquid fraction bacteria. Both the 48-h bag residues and 24-h bag residues (on $16 \mathrm{~d}$ ) were processed, with the barley silage and concentrate processed separately, to obtain the FPA and the feed particle-bound (FPB) bacterial fractions. Bag residues were removed from the fermentation vessels and gently squeezed, and then were placed in a plastic bag with $20 \mathrm{~mL}$ of McDougall's buffer and processed for $60 \mathrm{~s}$ in a Stomacher 400 laboratory blender (Seward Medical Ltd., London, UK). The processed liquid was gently squeezed out, poured off, and retained. The feed residues were washed 2 additional times using $10 \mathrm{~mL}$ of buffer in each wash. All wash buffer was retained and pooled with the initially expressed fluid to obtain the FPA bacterial fraction, and the total volume was recorded. The washed, solid feed residues were representative of the FPB bacterial fraction.

To determine ${ }^{15} \mathrm{~N}$ concentration, effluent liquid samples were centrifuged $\left(20,000 \times \mathrm{g}, 30 \mathrm{~min}, 4^{\circ} \mathrm{C}\right)$ and the resulting pellets were washed using deionized water and centrifuged 3 times $\left(20,000 \times \mathrm{g}, 30 \mathrm{~min}, 4^{\circ} \mathrm{C}\right)$. The pellet was then resuspended in distilled water and frozen at $-20^{\circ} \mathrm{C}$ until it was lyophilized. The FPA bacterial samples collected from the stomaching process were centrifuged $\left(500 \times \mathrm{g}, 10 \mathrm{~min}, 4^{\circ} \mathrm{C}\right)$. The supernatant was poured off, centrifuged again $\left(20,000 \times g, 30 \mathrm{~min}, 4^{\circ} \mathrm{C}\right)$, and the resulting pellet was washed 3 times as previously described. The pellet was then resuspended in distilled water and frozen at $-20^{\circ} \mathrm{C}$ until it was lyophilized. Washed feed residues (FPB fraction) were dried at $55^{\circ} \mathrm{C}$ for $48 \mathrm{~h}$, weighed for DM determination, ground, and frozen at $-40^{\circ} \mathrm{C}$ until analyzed for total $\mathrm{N}$ and ${ }^{15} \mathrm{~N}$ concentrations.

\section{Sample Collection: DF Fermenter}

Diet Digestibility. From d 9 to 16, daily effluent was homogenized and a $250-\mathrm{mL}$ subsample was taken, centrifuged $\left(20,000 \times \mathrm{g}, 30 \mathrm{~min}, 4^{\circ} \mathrm{C}\right)$, and the solid fraction was dried at $55^{\circ} \mathrm{C}$ for $48 \mathrm{~h}$ for the determination of DM (indigestible portion plus microbial fraction). The daily undigested residues were subsequently analyzed for $\mathrm{OM}, \mathrm{NDF}, \mathrm{ADF}$, and total $\mathrm{N}$.
Fermentation Gases and End-Products. Fermenter $\mathrm{pH}$ was recorded at 2-h intervals daily using a pH meter (model 4505, Chemtrix, Inc., Hillsboro, OR). On d 9 to 16, just prior to the morning feeding, gas samples were taken from the septum located on the top of the fermenter using a 26-gauge needle (Becton Dickinson) and 20-mL samples were transferred to evacuated 6.8-mL exetainers (Labco Ltd.) for immediate analysis of $\mathrm{CH}_{4}$. At the same time, 4.0-mL subsamples of fermenter liquid were taken directly from the fermenters and preserved as previously described for the Rusitec for analysis of $\mathrm{NH}_{3}-\mathrm{N}$ and VFA concentrations. Samples were stored at $-20^{\circ} \mathrm{C}$ until analyzed.

Protozoa Enumeration. During the sampling period (d 9 to 16 ), $5.0-\mathrm{mL}$ subsamples of fermentation media were taken directly from the fermenters just prior to the morning feeding and processed as described previously with Rusitec samples for subsequent enumeration of protozoa.

Microbial Protein Synthesis. Microbial protein synthesis was estimated using ${ }^{15} \mathrm{~N}$ as a microbial marker. On d 8, McDougall's buffer solution was modified by replacing the $\left(\mathrm{NH}_{4}\right)_{2} \mathrm{SO}_{4}$ with ${ }^{15} \mathrm{~N}$-enriched $\left(\mathrm{NH}_{4}\right)_{2} \mathrm{SO}_{4}$ $\left(1.0 \mathrm{~g} / \mathrm{L}\right.$; Sigma Chemical Co., minimum ${ }^{15} \mathrm{~N}$ enrichment 10.01 atom \%). On the last $2 \mathrm{~d}$ of the sampling period (d 15 to 16), the effluent was homogenized and filtered through 2 layers of preweighed cheesecloth. A 500-mL subsample was taken from the filtered liquid and centrifuged as described previously for the Rusitec samples to isolate liquid-associated bacteria. The solid fraction of the effluent retained in the cheesecloth was lyophilized, weighed for DM determination, and subsequently ground for measurement of total $\mathrm{N}$ and ${ }^{15} \mathrm{~N}$.

\section{Chemical Analyses}

Analytical DM content of barley silage, concentrate, effluent feed residue in the DF, and the undigested feed residues of both barley silage and concentrate contained in the polyester bags in the Rusitec were determined by oven drying at $105^{\circ} \mathrm{C}$ for $48 \mathrm{~h}$ in a forced-air oven (AOAC, 1990, method 930.15). Ash content of barley silage, concentrate, and the effluent feed residue in the DF was determined by combustion at $550^{\circ} \mathrm{C}$ overnight, and $\mathrm{OM}$ was subsequently calculated as 100 minus the percentage ash (AOAC, 1990, method 942.05). Total $\mathrm{N}$ content of barley silage, concentrate, effluent feed residue in the $\mathrm{DF}$, and the undigested feed residues of both barley silage and concentrate contained in the polyester bags in the Rusitec was determined by combustion assay (model NA 1500, Carlo Erba Instruments, Rodano, Italy). Crude protein was calculated as $\mathrm{N} \times 6.25$. The $\mathrm{NDF}$ (Van Soest et al., 1991) and ADF (AOAC, 1990, method 973.18) contents from barley silage, concentrate, the effluent 
feed residue in the DF, and the undigested feed residues of both silage and concentrate in the Rusitec were determined using an Ankom ${ }^{200}$ fiber analyzer (Ankom Technology Corp., Fairport, NJ). Heat-stable $\alpha$-amylase and sodium sulfite were used during the NDF procedure. Volatile fatty acid concentration was determined by GLC (Hewlett-Packard model 5890, Agilent Technologies, Mississauga, ON, Canada) equipped with a 30-m (0.32$\mathrm{mm}$ i.d.) Zebron FFAP column (Phenomenex, Florence, CA). The concentration of $\mathrm{NH}_{3}-\mathrm{N}$ in fermentation fluid samples was determined using the phenol-hypochlorite procedure adapted for a Technicon Autoanalyzer II (Broderick and Kang, 1980). Methane concentration in the gas sample was determined using a Varian 3600 gas chromatograph equipped with 180-cm Poropak QS (Alltech and Associates Inc., Deerfield, IL). Nitrogen gas was used as the carrier gas at a flow rate of $30 \mathrm{~mL} / \mathrm{min}$. Total $\mathrm{N}$ and ${ }^{15} \mathrm{~N}$ content of the bacterial pellets were determined by mass spectrometry using a model NA $1500 \mathrm{~N}$ analyzer (Carlo Erba Instruments).

\section{Calculations}

For the Rusitec, incorporation of ${ }^{15} \mathrm{~N}$ into microbial $\mathrm{N}$ in the effluent, FPA, and FPB fractions was calculated based on sample size (weight and volume) and ${ }^{15} \mathrm{~N}$ enrichment in the fractions produced daily. Total microbial ${ }^{15} \mathrm{~N}$ incorporation was calculated as the sum of incorporations in the effluent, 24-h, and 48-h feed bags (Wang et al., 2001).

Microbial N (MN) yield in both CC systems (in milligrams) was estimated using the following equation:

$$
\mathrm{MN}=\frac{\mathrm{APE} \text { in } \mathrm{RN}}{\mathrm{APE} \text { in } \mathrm{MN}} \times \mathrm{RN}
$$

where APE in RN is the percent excess of ${ }^{15} \mathrm{~N}$ in the solid residue, APE in MN is the percent excess of ${ }^{15} \mathrm{~N}$ in the microbial fraction of the effluent, and $\mathrm{RN}$ is the total $\mathrm{N}$ in the residue (in milligrams; Wang et al., 2000).

\section{Statistical Analyses}

For each CC system, data were analyzed as repeated measures using the MIXED procedure of SAS (SAS Institute, 2000). The MIXED model accounted for the repeated measures (sampling day), the fixed effects of treatment, and the interaction between treatment and sampling day. Results are reported as least squares means ( \pm SEM). Significance was declared at $P \leq 0.05$ and a trend at $0.05<P \leq 0.15$ unless otherwise stated. Protozoal counts yielded a nonnormal distribution and normality was unable to be induced via log transformation; therefore, only mean protozoal counts $( \pm$ SEM) are reported.

\section{RESULTS}

\section{Rusitec}

There was no interaction $(P>0.05)$ between treatment and sampling day for ruminal $\mathrm{pH}$ and total VFA concentration, which increased $(P<0.01)$ and decreased $(P<$ 0.01 ), respectively, with CIN addition (Table 2). However, there were interactions between treatment and sampling day for $\mathrm{NH}_{3}-\mathrm{N}$ concentration $(P=0.04)$ and molar proportions of acetate $(P<0.01)$, propionate $(P<$ $0.01)$, butyrate $(P<0.01)$, isobutyrate $(P=0.02$; data not shown), and valerate $(P<0.01$; data not shown). The concentration of $\mathrm{NH}_{3}-\mathrm{N}$ was similar between treatments on d 9 (i.e., first day of CIN administration) but was lower for CIN than for CON on d 10 to 16 . The magnitude of decrease in $\mathrm{NH}_{3}-\mathrm{N}$ concentration increased from $\mathrm{d} 10$ to 12 and remained unchanged from $\mathrm{d} 12$ until the end of the experimental period (Figure 1). The molar proportion of acetate was similar between treatments on $d 9$ and 13, but was lower from d 10 to 12 and higher on d 14 to 16 with CIN than with CON (Figure 2a). Addition of CIN decreased the molar proportion of propionate and the magnitude of this decrease increased over sampling days (Figure 2b). The butyrate molar proportion was similar between treatments on d 9, and increased on d 10 to 16 with CIN addition. The magnitude of this change increased from d 10 to 11 and remained constant from $\mathrm{d} 11$ to the end of the sampling period (Figure 2c). The molar proportion of valerate was similar between treatments on d 9, but was increased with CIN addition on d 10 to 13 and did not differ between treatments from d 14 to the end of the experiment (data not shown). The isobutyrate molar proportion was similar between treatments on $\mathrm{d} 9$ to 10 , but was lower for CIN than for CON on $d 11$ to 16 (data not shown). There was no treatment $\times$ sampling day interaction for the molar proportion of isovalerate, which was lower for CIN than for $\mathrm{CON}(P<0.01)$. The acetate:propionate ratio was similar between treatments from $d 9$ to 11, but was higher for CIN than for CON from d 12 to 16 (data not shown), resulting in a treatment $\times$ sampling day interaction $(P=0.01)$.

There was no interaction $(P=0.13)$ between treatment and sampling day for total gas production, which was lower $(P=0.01)$ for CIN than for CON. However, $\mathrm{CH}_{4}$ concentration was similar between treatments on $\mathrm{d} 9$ to 10 and $d 15$ to 16 but was lower for CIN than for CON on d 11 to 14 (data not shown), resulting in a treatment $\times$ sampling day interaction $(P<0.01)$.

Effects of CIN addition on nutrient disappearance measured in the Rusitec are presented in Table 3. There was an interaction $(P=0.05)$ between treatment and sampling day for apparent DM disappearance of barley silage at $48 \mathrm{~h}$, which was lower for CIN than for CON. 
Table 2. Effects of the essential oil from cinnamon leaf (CIN) on the fermentation characteristics measured using the rumen simulation technique (Rusitec)

\begin{tabular}{|c|c|c|c|c|c|c|}
\hline \multirow[b]{3}{*}{ Item } & \multirow{2}{*}{\multicolumn{2}{|c|}{ Treatment }} & \multirow[b]{3}{*}{ SEM } & \multicolumn{3}{|c|}{$\operatorname{Effect}^{1}(P=)$} \\
\hline & & & & \multirow[b]{2}{*}{ Trt } & \multirow{2}{*}{$\begin{array}{l}\text { Sampling } \\
\text { day }\end{array}$} & \multirow{2}{*}{$\begin{array}{c}\text { Trt } \times \text { sampling } \\
\text { day }\end{array}$} \\
\hline & Control & CIN & & & & \\
\hline $\mathrm{pH}$ & 6.88 & 6.94 & 0.008 & $<0.01$ & $<0.01$ & 0.76 \\
\hline $\mathrm{NH}_{3}-\mathrm{N}, \mathrm{mg} / \mathrm{L}$ & 21.3 & 15.1 & 0.49 & $<0.01$ & $<0.01$ & 0.04 \\
\hline Total VFA, $\mathrm{m} M$ & 43.3 & 25.5 & 1.70 & $<0.01$ & 0.72 & 0.28 \\
\hline \multicolumn{7}{|l|}{ VFA, mol/100 mol } \\
\hline Acetate $(\mathrm{A})$ & 52.9 & 53.8 & 1.05 & 0.55 & $<0.01$ & $<0.01$ \\
\hline Propionate $(\mathrm{P})$ & 26.1 & 13.0 & 0.62 & $<0.01$ & $<0.01$ & $<0.01$ \\
\hline Butyrate & 14.2 & 25.8 & 0.81 & $<0.01$ & $<0.01$ & $<0.01$ \\
\hline Isobutyrate & 1.02 & 0.71 & 0.043 & $<0.01$ & $<0.01$ & 0.02 \\
\hline Valerate & 4.27 & 5.70 & 0.389 & 0.04 & $<0.01$ & $<0.01$ \\
\hline Isovalerate & 1.49 & 1.00 & 0.101 & $<0.01$ & $<0.01$ & 0.28 \\
\hline A:P & 2.04 & 7.95 & 0.685 & $<0.01$ & $<0.01$ & 0.01 \\
\hline Gas production, $\mathrm{mL} / 24 \mathrm{~h}$ & 1,338 & 1,071 & 52 & 0.01 & 0.10 & 0.13 \\
\hline $\mathrm{CH}_{4}, \%$ in gas & 2.21 & 1.84 & 0.184 & 0.19 & 0.01 & $<0.01$ \\
\hline
\end{tabular}

\footnotetext{
${ }^{1}$ Probabilities associated with $F$-tests for treatment (Trt), sampling day, and the interaction between
} treatment and sampling day.

The magnitude of this decrease increased over sampling days (data not shown). There was no interaction $(P>$ 0.05 ) between treatment and sampling day for the disappearance of any other measured nutrients. Addition of CIN reduced $(P<0.01)$ apparent DM and $\mathrm{N}$ disappearance of concentrate at $48 \mathrm{~h}$ but did not affect $(P=0.81)$ apparent $\mathrm{N}$ disappearance of barley silage at $48 \mathrm{~h}$. The 48-h disappearance of NDF from barley silage tended $(P=0.11)$ to decrease and that of the concentrate was reduced $(P<0.01)$ by CIN. Supplementation with CIN also decreased $\mathrm{ADF}$ disappearance of both the barley silage $(P<0.01)$ and the concentrate $(P<0.01)$. The addition of CIN reduced protozoa numbers $(46.9 \pm 166.3$ vs. $2,314.7 \pm 352.5$ protozoa/mL) by as much as 2 logs.

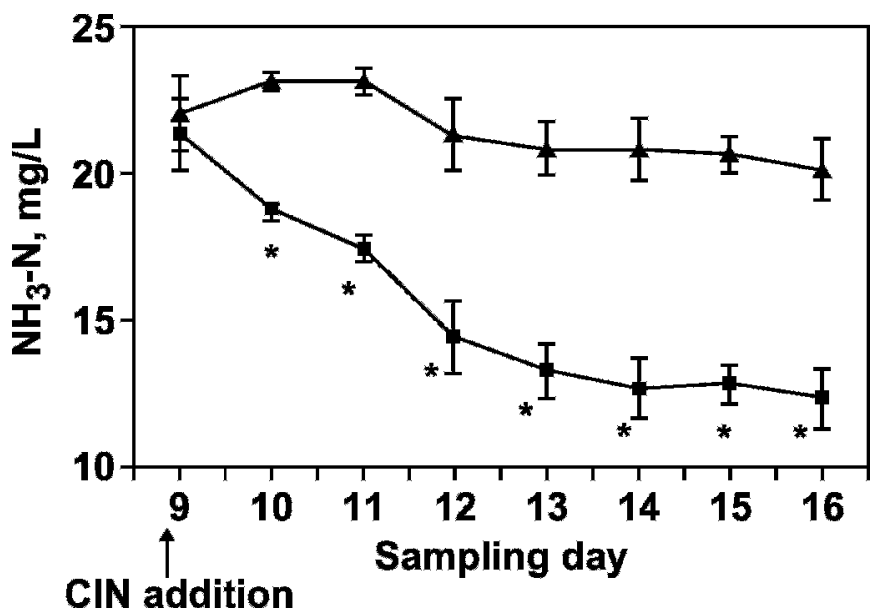

Figure 1. Effect of cinnamon leaf essential oil (CIN, $\square$ ) on $\mathrm{NH}_{3-}$ $\mathrm{N}$ concentration $(\mathrm{mg} / \mathrm{L})$ in the Rusitec over sampling days compared with the control $(\mathbf{\Delta})$. * Means differ from the control; $P<0.05$.
Effects of CIN addition on microbial protein synthesis measured in the Rusitec are presented in Table 4. Total microbial incorporation of ${ }^{15} \mathrm{~N}$ (i.e., total of all bacterial fractions: effluent, FPA, and FPB) was increased ( $P=$ $0.03)$ by the addition of CIN. In the effluent fraction, enrichment of ${ }^{15} \mathrm{~N}$ into microbial $\mathrm{N}$ was increased $(P=$ 0.02 ) in the treatment fermenters. In the FPA bacterial fraction, the addition of CIN tended to reduce $(P=0.07)$ and reduced $(P=0.04){ }^{15} \mathrm{~N}$ incorporation into microbial $\mathrm{N}$ in barley silage at 24 and $48 \mathrm{~h}$, respectively. For the concentrate, CIN reduced $(P=0.03)$ the incorporation of ${ }^{15} \mathrm{~N}$ into the FPA bacterial fraction at $24 \mathrm{~h}$, whereas no effect was observed at $48 \mathrm{~h}$. In the FPB fraction, CIN increased ${ }^{15} \mathrm{~N}$ incorporation into microbial $\mathrm{N}$ from the barley silage and concentrate feeds at both $24 \mathrm{~h}(P=$ $0.05)$ and $48 \mathrm{~h}(P=0.04)$. Estimated total production of microbial $\mathrm{N}$ (i.e., from all bacterial fractions) tended ( $P=$ 0.12 ) to be lower with the CIN treatment than with CON (Table 4). Estimated production of microbial $\mathrm{N}$ in the effluent bacterial fraction was not changed $(P=0.38)$ by CIN addition. In the FPA bacterial fraction, CIN reduced the production of microbial $\mathrm{N}$ from both the barley silage $(P<0.01)$ and concentrate $(P<0.01)$ at both 24 and $48 \mathrm{~h}$. In the FPB fraction, the production of microbial $\mathrm{N}$ from barley silage was unaffected by the CIN treatment at $24(P=0.41)$ and $48 \mathrm{~h}(P=0.88)$, whereas it was increased $(P<0.01)$ by CIN from the concentrate at both incubation times.

\section{DF Fermenter}

No treatment $\times$ sampling day interactions $(P>0.05)$ were observed for the various ruminal fermentation characteristics measured in the DF (Table 5). Addition 
a)

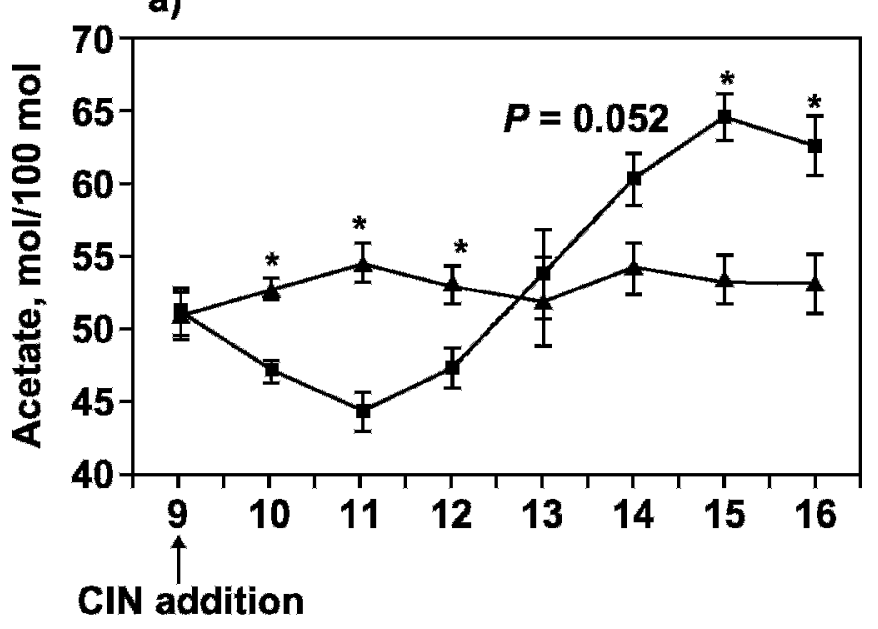

b)
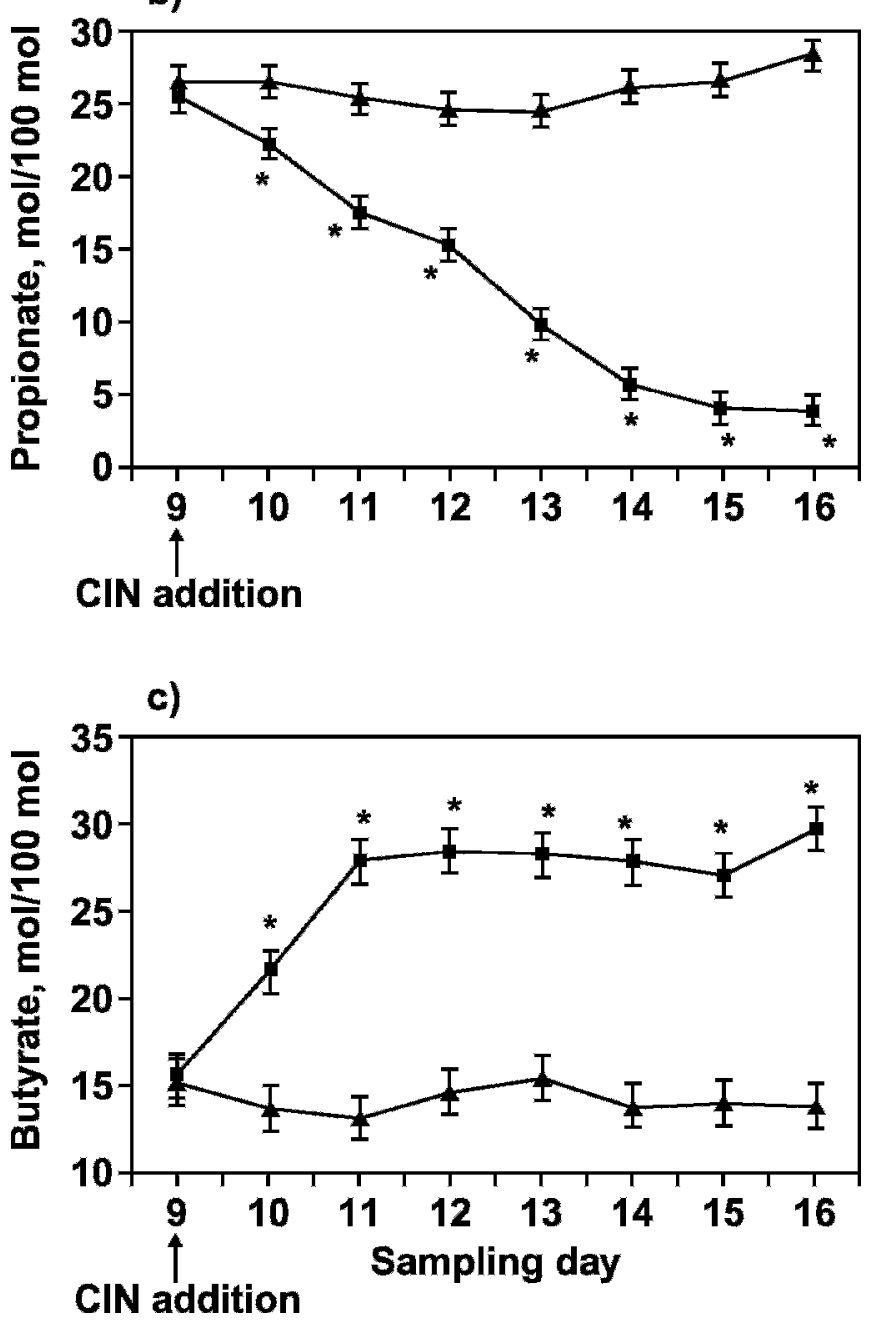

Figure 2. Effect of cinnamon leaf essential oil (CIN, 口) on molar proportions ( $\mathrm{mol} / 100 \mathrm{~mol}$ ) of a) acetate, $\mathrm{b}$ ) propionate, and c) butyrate in the Rusitec over sampling days compared with the control $(\mathbf{\Delta})$. * Means differ from the control; $P<0.05$. of CIN had no effect on fermenter $\mathrm{pH}(P=0.68), \mathrm{NH}_{3}$ $\mathrm{N}(P=0.17)$, total VFA concentration $(P=0.60)$, or acetate molar proportion $(P=0.75)$. The interaction between sampling day and treatment tended $(P=0.06)$ to be significant for the molar proportion of propionate, which was not changed by CIN addition on $d 9$, but decreased on $\mathrm{d} 10$ to 16 (Figure 3). The magnitude of this decrease increased from $d 10$ to 13 and remained constant from d 14 until the end of the sampling period. In contrast, adding CIN increased $(P=0.02)$ the butyrate molar proportion, and no change was observed for isobutyrate $(P=0.78)$, valerate $(P=0.50)$, or isovalerate $(P=$ 0.93 ) molar proportions. A treatment $\times$ sampling day interaction was observed $(P=0.04)$ for the acetate:propionate ratio, which was similar between treatments on d 9 but was increased by CIN from d 10 to 16 . The magnitude of this increase remained constant from $\mathrm{d} 13$ to 16 (data not shown). There was a trend $(P=0.07)$ for an interaction between treatment and sampling day for $\mathrm{CH}_{4}$ concentration, expressed as a percentage of total fermentation gas. On d 9 to 10 and $\mathrm{d} 14$ to $16, \mathrm{CH}_{4}$ concentration was similar between treatments but was increased by CIN on d 11 to 13 (data not shown).

Effects of CIN addition on nutrient digestibility measured in the DF are presented in Table 6. There were interactions between treatment and sampling day for DM $(P=0.03)$ and OM $(P=0.05)$ digestibilities. For both variables (data not shown), DM and OM digestibilities were similar $(P>0.05)$ between treatments on d 9 to 10 and d 13 to 14 , but were decreased $(P<0.05)$ by CIN addition on $\mathrm{d} 11$ to 12 . On $\mathrm{d} 15, \mathrm{DM}$ and $\mathrm{OM}$ digestibilities increased with addition of CIN; however, on $d 16$ they were similar between treatments. Conversely, no treatment $\times$ sampling day interaction $(P>$ 0.05 ) was observed for the digestibility of NDF and ADF, which were reduced ( $P=0.03$ and $<0.01$, respectively) with CIN addition. Protozoa numbers were reduced $(P$ $<0.05)$ by the addition of CIN in DF $(390.0 \pm 959.7$ vs. $3,939.1 \pm 987.2$ protozoa $/ \mathrm{mL})$.

Flow of total N $(P=0.48), \mathrm{NH}_{3}-\mathrm{N}(P=0.21)$, NAN $(P=0.31)$, and dietary $\mathrm{N}(P=0.64)$ were unaffected by CIN addition (Table 7). However, adding CIN decreased $(P=0.01)$ microbial $\mathrm{N}$ flow and efficiency of microbial protein synthesis $(P=0.01)$. Degradation of $\mathrm{CP}$ tended $(P=0.06)$ to decrease with CIN supplementation.

\section{DISCUSSION}

\section{Ruminal Fermentation Characteristics and Nutrient Digestion}

In the present study, $2 \mathrm{CC}$ systems were used to evaluate $\mathrm{EO}$ from cinnamon leaf for its potential as a ruminal modifier. To our knowledge, this is the first time that 
Table 3. Effects of the essential oil from cinnamon leaf (CIN) on apparent disappearances of DM, NDF, and $\mathrm{ADF}$ measured using the rumen simulation technique (Rusitec)

\begin{tabular}{|c|c|c|c|c|c|c|}
\hline \multirow[b]{3}{*}{ Item } & \multirow{2}{*}{\multicolumn{2}{|c|}{ Treatment }} & \multirow[b]{3}{*}{ SEM } & \multicolumn{3}{|c|}{$\operatorname{Effect}^{1}(P=)$} \\
\hline & & & & & Sampling & Trt $\times$ sampling \\
\hline & Control & CIN & & Trt & day & day \\
\hline \multicolumn{7}{|c|}{ DM disappearance at $48 \mathrm{~h}, \%$} \\
\hline Barley silage & 59.8 & 48.8 & 0.64 & $<0.01$ & 0.39 & 0.05 \\
\hline Concentrate & 82.1 & 68.0 & 1.31 & $<0.01$ & 0.32 & 0.60 \\
\hline \multicolumn{7}{|c|}{$\mathrm{N}$ disappearance at $48 \mathrm{~h}, \%$} \\
\hline Barley silage & 57.6 & 57.2 & 1.11 & 0.81 & 0.63 & 0.23 \\
\hline Concentrate & 71.3 & 55.4 & 2.76 & $<0.01$ & 0.67 & 0.99 \\
\hline \multicolumn{7}{|c|}{ NDF disappearance at $48 \mathrm{~h}, \%$} \\
\hline Barley silage & 29.9 & 29.1 & 0.30 & 0.11 & 0.16 & 0.60 \\
\hline Concentrate & 21.0 & 14.0 & 1.21 & $<0.01$ & $<0.01$ & 0.49 \\
\hline \multicolumn{7}{|c|}{ ADF disappearance at $48 \mathrm{~h}, \%$} \\
\hline Barley silage & 6.41 & 5.06 & 0.161 & $<0.01$ & 0.25 & 0.55 \\
\hline Concentrate & 7.04 & 4.52 & 0.457 & $<0.01$ & 0.39 & 0.36 \\
\hline
\end{tabular}

${ }^{1}$ Probabilities associated with $F$-tests for treatment (Trt), sampling day, and the interaction between treatment and sampling day.

these 2 types of CC systems were used simultaneously in the same experiment.

In the Rusitec, CIN addition increased fermenter $\mathrm{pH}$ and decreased total VFA concentration, indicating that the CIN reduced diet fermentability, an observation consistent with the antimicrobial activity of EO compounds
(Acamovic and Brooker, 2005). Results presented here are consistent with results on the effects of EO compounds at high doses, as reported in previous in vitro studies (Evans and Martin, 2000; Castillejos et al., 2006). Using 24-h batch cultures, Castillejos et al. (2006) reported that at a high dose $(5,000 \mathrm{mg} / \mathrm{L})$, eugenol, guaia-

Table 4. Effect of the essential oil from cinnamon leaf (CIN) on incorporation of ${ }^{15} \mathrm{~N}$ into microbial $\mathrm{N}$ in effluent, feed particle-associated (FPA), and feed particle-bound (FPB) fractions during 24- and 48-h incubations of barley silage and concentrate in the rumen simulation technique (Rusitec)

\begin{tabular}{|c|c|c|c|c|}
\hline \multirow[b]{2}{*}{ Fraction } & \multicolumn{2}{|c|}{ Treatment } & \multirow[b]{2}{*}{ SEM } & \multirow{2}{*}{$\begin{array}{r}\text { Effect } \\
(P=)\end{array}$} \\
\hline & Control & CIN & & \\
\hline \multicolumn{5}{|c|}{ Microbial incorporation of ${ }^{15} \mathrm{~N}$} \\
\hline Total, ${ }^{2} \mu \mathrm{g} / 24 \mathrm{~h}$ & $1,905.5$ & $2,244.7$ & 84.05 & 0.02 \\
\hline Effluent, $\mu \mathrm{g} / 24 \mathrm{~h}$ & $1,226.6$ & $1,468.8$ & 51.44 & 0.02 \\
\hline Silage, $\mu \mathrm{g} / 24 \mathrm{~h}$ & 133.0 & 91.5 & 13.12 & 0.07 \\
\hline Silage, $\mu \mathrm{g} / 48 \mathrm{~h}$ & 99.8 & 71.3 & 7.79 & 0.04 \\
\hline Concentrate, $\mu \mathrm{g} / 24 \mathrm{~h}$ & 122.9 & 90.6 & 7.71 & 0.03 \\
\hline Concentrate, $\mu \mathrm{g} / 48 \mathrm{~h}$ & 118.6 & 99.8 & 11.42 & 0.29 \\
\hline \multicolumn{5}{|l|}{ FPB } \\
\hline Silage, $\mu \mathrm{g} / 24 \mathrm{~h}$ & 55.1 & 80.8 & 7.54 & 0.05 \\
\hline Silage, $\mu \mathrm{g} / 48 \mathrm{~h}$ & 86.5 & 118.5 & 8.88 & 0.04 \\
\hline Concentrate, $\mu \mathrm{g} / 24 \mathrm{~h}$ & 30.3 & 105.4 & 13.11 & $<0.01$ \\
\hline Concentrate, $\mu \mathrm{g} / 48 \mathrm{~h}$ & 32.9 & 168.04 & 5.80 & $<0.01$ \\
\hline \multicolumn{5}{|l|}{ Production of microbial $\mathrm{N}$} \\
\hline Total, mg/24 h & 58.8 & 53.2 & 2.20 & 0.12 \\
\hline Effluent, mg/24 h & 37.5 & 35.1 & 1.78 & 0.38 \\
\hline \multicolumn{5}{|l|}{ FPA } \\
\hline Silage, mg/24 h & 3.67 & 2.07 & 0.189 & $<0.01$ \\
\hline Silage, mg/48 h & 2.92 & 1.55 & 0.138 & $<0.01$ \\
\hline Concentrate, mg/24 h & 3.43 & 1.75 & 0.231 & $<0.01$ \\
\hline Concentrate, $\mathrm{mg} / 48 \mathrm{~h}$ & 4.90 & 2.41 & 0.462 & $<0.01$ \\
\hline \multicolumn{5}{|l|}{ FPB } \\
\hline Silage, mg/24 h & 1.80 & 1.69 & 0.086 & 0.41 \\
\hline Silage, mg/48 h & 2.53 & 2.56 & 0.178 & 0.88 \\
\hline Concentrate, $\mathrm{mg} / 24 \mathrm{~h}$ & 0.89 & 2.38 & 0.202 & $<0.01$ \\
\hline Concentrate, $\mathrm{mg} / 48 \mathrm{~h}$ & 1.18 & 3.66 & 0.139 & $<0.01$ \\
\hline
\end{tabular}

${ }^{1}$ Probabilities associated with $F$-tests for effect of treatment.

${ }^{2}$ Total incorporation is the sum of all incorporations in the effluent, FPA and FPB fractions obtained from both the silage and concentrate feed bags. 
Table 5. Effects of the essential oil from cinnamon leaf (CIN) on rumen fermentation characteristics measured in the dual-flow continuous culture system

\begin{tabular}{|c|c|c|c|c|c|c|}
\hline \multirow[b]{3}{*}{ Item } & \multirow{2}{*}{\multicolumn{2}{|c|}{ Treatment }} & \multirow[b]{3}{*}{ SEM } & \multicolumn{3}{|c|}{$\operatorname{Effect}^{1}(P=)$} \\
\hline & & & & \multirow[b]{2}{*}{ Trt } & \multirow{2}{*}{$\begin{array}{c}\text { Sampling } \\
\text { day }\end{array}$} & \multirow{2}{*}{$\begin{array}{c}\text { Trt } \times \text { sampling } \\
\text { day }\end{array}$} \\
\hline & Control & CIN & & & & \\
\hline $\mathrm{pH}$ & 7.00 & 6.96 & 0.079 & 0.68 & 0.11 & 0.59 \\
\hline $\mathrm{NH}_{3}-\mathrm{N}, \mathrm{mg} / \mathrm{L}$ & 18.6 & 19.9 & 0.60 & 0.17 & 0.10 & 0.22 \\
\hline Total VFA, mM & 75.6 & 69.4 & 8.01 & 0.60 & 0.53 & 0.57 \\
\hline \multicolumn{7}{|l|}{ VFA, mol/100 mol } \\
\hline Acetate (A) & 69.7 & 68.2 & 1.62 & 0.51 & 0.75 & 0.49 \\
\hline Propionate (P) & 15.1 & 9.4 & 0.54 & $<0.01$ & 0.02 & 0.06 \\
\hline Butyrate & 10.3 & 17.1 & 1.72 & 0.02 & 0.52 & 0.28 \\
\hline Isobutyrate & 1.07 & 1.03 & 0.096 & 0.78 & 0.89 & 0.94 \\
\hline Valerate & 2.11 & 2.37 & 0.267 & 0.50 & 0.47 & 0.99 \\
\hline Isovalerate & 1.80 & 1.83 & 0.234 & 0.93 & 0.57 & 0.75 \\
\hline A:P & 4.69 & 7.65 & 0.556 & 0.01 & 0.04 & 0.04 \\
\hline $\mathrm{CH}_{4}, \%$ in gas & 3.36 & 5.58 & 1.042 & 0.20 & $<0.01$ & 0.07 \\
\hline
\end{tabular}

${ }^{1}$ Probabilities associated with $F$-tests for treatment (Trt), sampling day, and the interaction between treatment and sampling day.

col, limonene, thymol, and vanillin reduced total VFA concentration and consequently increased $\mathrm{pH}$ compared with the control. However, in the same study, at a dose of $500 \mathrm{mg} / \mathrm{L}$, effects on ruminal $\mathrm{pH}$ and VFA concentration were apparent with limonene but not with the other EO examined. Using $24-\mathrm{h}$ in vitro batch cultures of mixed ruminal bacteria, Evans and Martin (2000) reported that thymol at a dose of $400 \mathrm{mg} / \mathrm{L}$ increased $\mathrm{pH}$ in the fermentation cultures, whereas at doses of 50,100, and $200 \mathrm{mg} / \mathrm{L}$, no effects were observed. Because the production of VFA serves as the principal source of energy for the ruminant animal, decreasing VFA production could yield adverse nutritional consequences if this same effect were expressed in vivo.

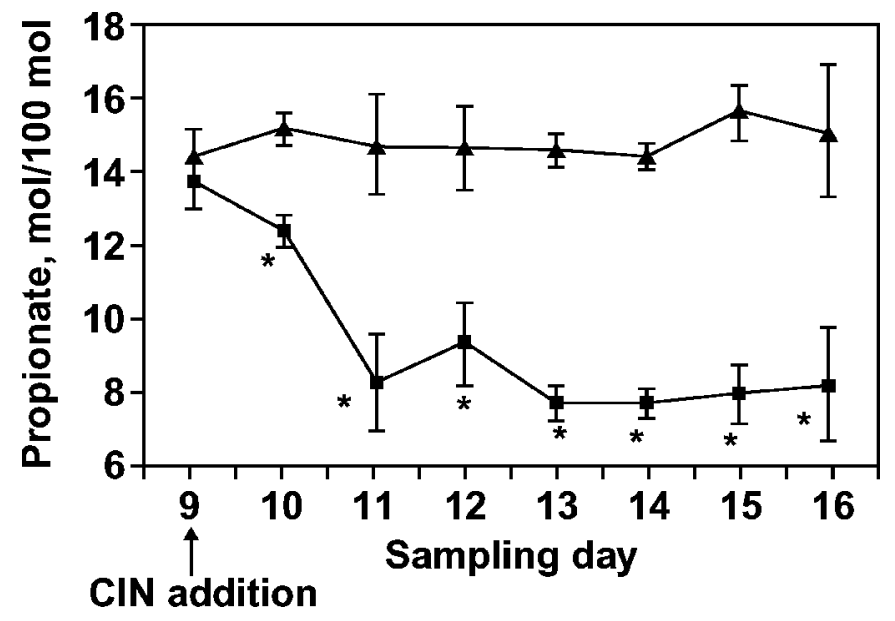

Figure 3. Effect of cinnamon leaf essential oil (CIN, ם) on the molar proportion $(\mathrm{mol} / 100 \mathrm{~mol})$ of propionate in the dual-flow fermenter over sampling days compared with control ( $\mathbf{\Delta})$. * Means significantly differ from the control; $P<0.05$.
The negative effect of CIN on nutrient digestion in the Rusitec corroborates the reduction in total VFA concentration and the concomitant increase in fermenter $\mathrm{pH}$. In the Rusitec, DM disappearance from both barley silage and concentrate was reduced; however, the magnitude of the reduction in DM disappearance was greater for concentrate than for barley silage. This may imply that microbial populations involved in concentrate digestion were more affected by CIN than those involved in barley silage digestion. Percentage of NDF disappearance from concentrate was decreased with CIN addition; however, that from barley silage was only slightly reduced, suggesting that the reduction in DM disappearance from the barley silage could be attributed to a decline in the soluble carbohydrate fraction of silage. The manner in which diet disappearance was altered might suggest that digestibility of the soluble carbohydrate fraction of the feedstuffs was more negatively affected than structural carbohydrate digestion.

In contrast to the effects observed with the Rusitec, CIN addition in the DF fermenter did not change ruminal $\mathrm{pH}$ or total VFA concentration. The lack of effect of CIN on total VFA concentration indicated that diet fermentability was not changed by CIN addition in the DF system as shown by apparent disappearances of DM and OM (Table 6). This discrepancy in the effects of CIN between the $2 \mathrm{CC}$ systems may be due to functional differences between the 2 types of fermenters, in particular the dilution rate, which was twice as high in the DF than in the Rusitec $(6.3 \mathrm{vs.} 2.9 \% / \mathrm{h})$, resulting in a lower effective concentration of CIN in the DF than in the Rusitec.

The antiprotozoal effect of the CIN may also contribute to the decrease in fiber digestibility observed in both $\mathrm{CC}$ systems, because it is estimated that protozoa con- 
Table 6. Effects of the essential oil from cinnamon leaf (CIN) on apparent disappearances of DM, OM, $\mathrm{NDF}$, and $\mathrm{ADF}$ in the dual-flow continuous culture system

\begin{tabular}{|c|c|c|c|c|c|c|}
\hline \multirow[b]{3}{*}{ Item } & \multirow{2}{*}{\multicolumn{2}{|c|}{ Treatment }} & \multirow[b]{3}{*}{ SEM } & \multicolumn{3}{|c|}{$\operatorname{Effect}^{1}(P=)$} \\
\hline & & & & & Sampling & $\operatorname{Trt} \times$ \\
\hline & Control & CIN & & Trt & day & sampling day \\
\hline \multicolumn{7}{|c|}{ Apparent disappearance, \% } \\
\hline DM & 54.2 & 53.2 & 0.39 & 0.12 & 0.06 & 0.03 \\
\hline $\mathrm{OM}$ & 52.6 & 51.5 & 0.43 & 0.10 & 0.02 & 0.05 \\
\hline NDF & 39.3 & 35.3 & 0.91 & 0.03 & 0.04 & 0.22 \\
\hline $\mathrm{ADF}$ & 13.8 & 11.2 & 0.15 & $<0.01$ & 0.79 & 0.61 \\
\hline
\end{tabular}

${ }^{1}$ Probabilities associated with $F$-tests for treatment (Trt), sampling day, and the interaction between treatment and sampling day.

tribute upward of 25 to $30 \%$ of total ruminal fiber digestion (Lee et al., 2000). Contrary to the antiprotozoal effect of CIN in the present study (2 log reductions), Newbold et al. (2004) and Benchaar et al. (2006, 2007) observed no change in protozoa numbers when sheep and dairy cows were fed a commercial mixture of EO compounds (Crina ruminants, Crina S. A., Switzerland) at doses of $100 \mathrm{mg} / \mathrm{d}$ and $2 \mathrm{~g} / \mathrm{d}$, respectively. The antiprotozoal effect observed in the current study could be explained by the high dose of CIN used compared with doses examined in vivo (Benchaar et al., 2006, 2007).

Despite the reduction in numbers of protozoa in the treatment fermenters, the contribution of $\mathrm{CH}_{4}$ gas to the total gas production in the Rusitec remained unchanged on d 9 to 10 and $d 15$ to 16 relative to the control, but was decreased by the CIN from d 11 to 14 . Ruminal protozoa play a significant role in $\mathrm{CH}_{4}$ production (Moss et al., 2000), because a direct relationship has been identified between rumen protozoa numbers and methanogenesis (Klieve and Hegarty, 1999). Rumen protozoa are estimated to provide a habitat for up to $20 \%$ of ruminal methanogens, and methanogens living on and within protozoa are thought to be responsible for an estimated $37 \%$ of $\mathrm{CH}_{4}$ emissions from ruminant animals (Klieve and Hegarty, 1999). Our results indicate that although a synergism between protozoa and methanogens exists, methanogens can still actively produce significant quantities of $\mathrm{CH}_{4}$ in the absence of a fully functional population of protozoa.

In the current study, a treatment $\times$ sampling day interaction was observed for the molar proportions of individual VFA (except for isovalerate) when CIN was administered in the Rusitec. In contrast, CIN addition in the DF did not result in a treatment $\times$ sampling day interaction for the molar proportions of individual VFA, with the exception of propionate $(P=0.06)$. The absence of an interaction effect in DF may be attributed to the lack of effect of CIN on rumen microbes due to the higher dilution rate and to the lower effective concentration of CIN in DF than in Rusitec.

Other in vitro studies using a DF fermenter under controlled pH conditions (Cardozo et al., 2004; Busquet et al., 2005a) also reported effects of EO and their compounds on molar proportions of individual VFA over days. Cardozo et al. (2004) noted that garlic, cinnamon, anise, oregano, and pepper extracts $(0.22 \mathrm{mg} / \mathrm{L}$ of culture

Table 7. Effects of the essential oil from cinnamon leaf (CIN) on $\mathrm{N}$ degradation and efficiency of microbial protein synthesis in the dual-flow continuous culture system

\begin{tabular}{lcccc}
\hline & \multicolumn{2}{c}{ Treatment } & & \\
\cline { 2 - 3 } Item & Control & CIN & SEM & $\begin{array}{c}\text { Effect }^{1} \\
(P=)\end{array}$ \\
\hline Dietary N input, g/d & 5.02 & 5.02 & - & - \\
N flow, mg/d & & & & \\
Total & 954.7 & 966.4 & 11.9 & 0.48 \\
Ammonia-N & 388.7 & 464.5 & 39.9 & 0.21 \\
NAN & 565.9 & 501.9 & 42.3 & 0.31 \\
Microbial & 324.4 & 286.4 & 9.10 & 0.01 \\
Dietary & 241.6 & 215.5 & 37.04 & 0.64 \\
EMPS & 21.8 & 19.2 & 0.63 & 0.01 \\
True CP degradation, \% of N intake ${ }^{3}$ & 87.4 & 86.5 & 0.34 & 0.06 \\
\hline
\end{tabular}

\footnotetext{
${ }^{1}$ Probabilities associated with $F$-tests for treatment (Trt), sampling day, and the interaction between treatment and sampling day.

${ }^{2}$ EMPS = efficiency of microbial protein synthesis (g of microbial N/kg of OM fermented).

${ }^{3}$ Corrected for microbial N.
} 
fluid) altered the molar proportions and total VFA concentration during the adaptation period ( 1 to 7 ). After d 7 of incubation, however, these effects disappeared, suggesting that the ruminal microbes were able to adapt to the presence of $\mathrm{EO}$ administered at this concentration. In contrast, Busquet et al. (2005a) observed no change in total VFA concentration and diet digestibility when cinnamaldehyde and garlic oil were administered at 31 and $312 \mathrm{mg} / \mathrm{mL}$ of culture fluid in a DF system under controlled $\mathrm{pH}$ conditions. However, changes in the VFA pattern (i.e., molar proportions of individual VFA) were apparent within $48 \mathrm{~h}$ after these EO compounds were added to the fermenter and remained unchanged until the end of the experimental period. The results of Busquet et al. (2005a) suggest that the adaptation of rumen microbes to EO (i.e., replacement of sensitive bacteria by more resistant bacteria) or lack thereof may be explained by the different dosages used. Rumen microbes are able to adapt to EO when these compounds are administered at low doses, but at higher doses, the effect of EO appears to be sustained over time (i.e., $9 \mathrm{~d}$ of continuous culture fermentation). Based on these observations, Cardozo et al. (2004) and Busquet et al. (2005c) warned that data from short-term in vitro studies may lead to erroneous conclusions and should be interpreted with caution. Therefore, there is a need for long-term in vivo studies to assess the efficacy of EO under in vivo conditions where rumen microbes are exposed for a longer period (i.e., weeks) compared with in vitro conditions (i.e., $9 \mathrm{~d}$ in continuous culture systems). It is interesting to note that in this study, similar to the study of Busquet et al. (2005a), some of the effects of CIN on ruminal fermentation were apparent within 2 to $3 \mathrm{~d}$ after the administration of this EO in both CC systems. The effects stabilized $3 \mathrm{~d}$ after CIN addition in the fermenters and remained unchanged until the end of the sampling period.

The chemical composition of EO may also have implications on the results observed at given dosages. Castillejos et al. (2006) observed variation in the effects of 5 different EO compounds (i.e., eugenol, guaiacol, limonene, thymol, and vanillin) at increasing dosage levels $(5,50,500$, and $5,000 \mathrm{mg} / \mathrm{L}$ of fermentation culture fluid) on fermentation products in 24-h batch culture of rumen fluid. At a dose of $5,000 \mathrm{mg} / \mathrm{L}$, all compounds decreased the concentration of total VFA. The monoterpene limonene reduced total VFA concentration at doses of 50 and $500 \mathrm{mg} / \mathrm{L}$, but did not alter molar proportions of individual VFA. The phenolic guaiacol reduced total VFA concentration at doses of 5 and $50 \mathrm{mg} / \mathrm{L}$ and altered the molar proportion of acetate, but for unknown reasons was not effective at altering total VFA concentration at $500 \mathrm{mg} / \mathrm{L}$. The aldehyde vanillin and the phenolic eugenol were ineffective at altering total VFA concentration at doses of 5,50 , or $500 \mathrm{mg} / \mathrm{L}$, and the phenolic thymol reduced total VFA concentration at a dose of $500 \mathrm{mg} / \mathrm{L}$. These results illustrate that effects of EO on rumen microbial activities vary with the chemical structure and the dose of the EO compound. This variability in the effect of EO on rumen fermentation as a result of differences in activity and composition suggests that it may be challenging to develop an EO extract that consistently results in a favorable change in the profile of VFA.

The pattern of VFA in both CC systems was marked by a reduction in the proportion of propionate and an increase in that of butyrate, a result that implies that CIN favored populations of bacteria that produce butyrate and may have inhibited those that produce propionate. In the rumen, many predominant gram-positive bacteria are involved in the fermentation processes that produce, among other end-products, acetate, butyrate, formate, lactate, and hydrogen (Stewart, 1991). Rumen amylolytic bacteria generally ferment soluble dietary carbohydrates (starches and sugars) to produce propionate and succinate as major end-products, and these bacteria are generally gram-negative (Van Soest, 1982; Stewart, 1991). A reduction in the digestibility of soluble carbohydrates in the Rusitec and changes in patterns of VFA in both systems suggest that CIN inhibited gramnegative bacteria to a greater extent than gram-positive bacteria. Because fiber disappearance was reduced by CIN in both systems, this hypothesis does not imply that gram-positive, cellulolytic bacteria were unaffected by CIN addition, but that the inhibitory effects were less pronounced in this subpopulation. Eugenol is the primary constituent of the EO extract from cinnamon leaf. Unlike the ruminal modifier monensin, which targets primarily gram-positive bacteria (Russell and Strobel, 1989), phenolic compounds have been shown to have a broad spectrum of activity against both gram-positive and gram-negative bacteria (Kim et al., 1995; Helander et al., 1998; Dorman and Deans, 2000; Lambert et al., 2001). The antibacterial activity of phenolic compounds such as eugenol has been associated with their ability to disrupt the outer cell membrane (Dorman and Deans, 2000; Walsh et al., 2003). Consequently, eugenol as the primary phenolic in CIN may have resulted in a general inhibition of both gram-positive and gram-negative bacteria, resulting in an overall decline in digestion and total VFA production.

Recent in vitro studies both in short-term batch culture and long-term CC have reported similar effects of high doses of phenolic EO compounds (e.g., eugenol, thymol, carvacrol) on rumen microbial fermentation (Evans and Martin, 2000; Busquet et al., 2005a, 2006; Castillejos et al., 2006). Evans and Martin (2000) observed a decrease in acetate and propionate concentrations and an increase in the acetate to propionate ratio when thy- 
mol $(400 \mathrm{mg} / \mathrm{L})$ was added in batch cultures of mixed ruminal bacteria. Using a DF fermenter maintained under controlled pH conditions, Castillejos et al. (2006) observed that thymol $(500 \mathrm{mg} / \mathrm{L})$ reduced digestibility of DM, OM, NDF, and $\mathrm{ADF}$, and reduced total VFA concentration and the molar proportion of acetate, whereas the molar proportions of propionate and butyrate were increased. Increases in butyrate in the study by Castillejos et al. (2006) were significant; as in our study, the molar proportion of butyrate exceeded that of propionate. In the same study, eugenol $(500 \mathrm{mg} / \mathrm{L})$ decreased total VFA concentration and the molar proportion of acetate, but increased the molar proportions of propionate and butyrate without altering feed digestibility relative to the control. Although eugenol is the main component of CIN, results of the present study using the DF differ from those of Castillejos et al. (2006). Discrepancies in the results between the 2 studies are probably due to interactions between the primary compound eugenol and the secondary compounds within CIN, but also to different experimental conditions. In the study of Castillejos et al. (2006), each experimental period consisted of $9 \mathrm{~d}$ ( $6 \mathrm{~d}$ for adaptation and $3 \mathrm{~d}$ for sampling) compared with $16 \mathrm{~d}$ ( $8 \mathrm{~d}$ for adaptation and $8 \mathrm{~d}$ for sampling) in our study. Fermentation conditions were maintained at a constant $\mathrm{pH}(6.4 \pm 0.05)$ in the experiment of Castillejos et al. (2006), whereas fermentation $\mathrm{pH}$ was not controlled in our study. Busquet et al. (2006) reported effects of the plant secondary metabolites eugenol and clove bud oil ( $85 \%$ of eugenol) at doses of $3,30,300$, and $3,000 \mathrm{mg} / \mathrm{L}$ in $24-\mathrm{h}$ in vitro batch cultures. Despite the high eugenol content of clove bud oil, this EO and its main component exerted different effects. At 3,000 mg/L, the molar proportion of butyrate was not changed by clove bud oil, but it was decreased the with the addition of eugenol. At $300 \mathrm{mg} / \mathrm{L}$, clove bud oil decreased acetate molar proportion, whereas eugenol exerted no effect. These results suggest that minor compounds within the clove bud EO acted synergistically with eugenol to produce the observed effects. It is equally possible that the fermentation responses observed in the present study were due to secondary components within CIN.

\section{Nitrogen Metabolism and Microbial Protein Synthesis}

In the Rusitec, addition of CIN decreased $\mathrm{NH}_{3}-\mathrm{N}$ concentration and proportions of isobutyrate and isovalerate, which arise from AA metabolism. These reductions may have been caused by a decrease in the disappearance of $\mathrm{N}$ from the concentrate, as $\mathrm{N}$ disappearance of barley silage was not changed. Therefore, changes in $\mathrm{NH}_{3}-\mathrm{N}$ and branched-chain VFA (BCVFA) concentra- tions may suggest that both proteolysis and deamination processes were inhibited by the addition of CIN.

In the DF, CIN slightly reduced $\mathrm{N}$ degradation $(P=$ 0.06 ); however, no changes were observed for $\mathrm{NH}_{3}-\mathrm{N}$ concentration or molar proportions of BCVFA, suggesting that CIN did not affect the proteolysis or deamination processes to the same extent as in the Rusitec. Consistent with the present study, recent studies have reported varied effects of EO containing phenolics on $\mathrm{NH}_{3}-\mathrm{N}$ concentration. Castillejos et al. (2006) observed no effect of thymol and eugenol on $\mathrm{NH}_{3}-\mathrm{N}$ concentration when administered at doses of 5,50 , and $500 \mathrm{mg} / \mathrm{L}$ in a DF fermenter under controlled $\mathrm{pH}$ conditions. In 24$\mathrm{h}$ batch cultures, Busquet et al. (2006) reported variable effects of various phenolic EO compounds on $\mathrm{NH}_{3}-\mathrm{N}$ concentration. At $300 \mathrm{mg} / \mathrm{L}$, eugenol tended to decrease $\mathrm{NH}_{3}-\mathrm{N}$ concentration and carvacrol exerted no effect. Oregano oil (69\% carvacrol) decreased $\mathrm{NH}_{3}-\mathrm{N}$ concentration and clove bud oil ( $85 \%$ eugenol) exerted no effect. At a dose of $3,000 \mathrm{mg} / \mathrm{L}$, all these EO compounds decreased $\mathrm{NH}_{3}-\mathrm{N}$ concentration. Again, responses to EO vary with the $\mathrm{EO}$ and the dose used; however, the reduction in $\mathrm{NH}_{3}-\mathrm{N}$ observed at high doses may in part be due to the reduction in overall diet fermentability. The fact that both $\mathrm{DM}$ and protein digestion were reduced in the present study suggests that the antimicrobial activity of EO are of a broad-spectrum nature.

In the Rusitec, CIN increased the total microbial incorporation of ${ }^{15} \mathrm{~N}$ without affecting the total production of microbial $\mathrm{N}$, a result that may reflect a shift of the bacterial populations toward those that utilize predominantly ammonia as a $\mathrm{N}$ source. The bacterium Butyrivibrio fibrisolvens utilizes ammonia and is considered a major producer of butyrate in the rumen (Miller and Jenesel, 1979). A predominance of this species may account for the increased proportion of butyrate observed with CIN treatment in the Rusitec.

The reduction in incorporation of ${ }^{15} \mathrm{~N}$ into the FPA bacterial fraction from silage at $24 \mathrm{~h}$ (tendency at $48 \mathrm{~h}$ ) and concentrate at $24 \mathrm{~h}$ suggests that the CIN may have inhibited the growth of secondary colonizing bacteria to a greater extent than primary colonizing bacteria. Secondary colonizers subsist on soluble substrates produced by primary colonizing or fibrolytic bacteria and may be more susceptible to antimicrobials within the biofilm community (McAllister et al., 1994). In the FPB fraction, microbial $\mathrm{N}$ production in the barley silage at both incubation times remained unaffected by treatment, further suggesting that the CIN did not inhibit primary colonizing cellulolytic bacteria as much as secondary colonizers.

The apparent increase in ${ }^{15} \mathrm{~N}$ incorporation into bacterial fractions may also result from the antiprotozoal effect of the CIN. Ruminal protozoa ingest large numbers 
of bacteria, decreasing net microbial production and bacterial protein flow from the rumen to the duodenum (Ivan et al., 2000). Consequently, bacterial predation by protozoa yields an inverse relationship between population numbers of these 2 groups of microorganisms (Russell, 2002). A reduction in protozoa as a result of inclusion of CIN could therefore lead to an increase in bacterial numbers due to a reduction in predatory activity.

In the DF, the lack of effect of CIN on the flow of nondigested feed $\mathrm{N}$ and $\mathrm{CP}$ degradation is consistent with the lack of effect of the CIN on $\mathrm{NH}_{3}-\mathrm{N}$ concentration and the molar proportions of BCVFA. Addition of CIN reduced the flow of microbial $\mathrm{N}$, which is consistent with the antimicrobial activity of EO and the tendency observed for reduced DM $(P=0.12)$ and OM $(P=0.10)$ disappearances. Microbial efficiency (expressed as milligrams of $\mathrm{N}$ produced per kilogram of ruminally fermented OM) was significantly reduced by CIN and can be accredited to the tendency for the reduction in $\mathrm{OM}$ digestion and the significant reduction in microbial $\mathrm{N}$ flow with CIN addition. Because production of microbial protein serves as a major source of high-quality protein for the animal and can account for between 50 to $90 \%$ of the protein entering the intestine (Beauchemin, 2002), inhibition of microbial protein synthesis could have negative effects on animal productivity.

\section{CONCLUSIONS}

In the present study, $2 \mathrm{CC}$ systems, the Rusitec and the DF fermenter, were used to evaluate CIN for its potential as a ruminal modifier. In the Rusitec, the EO from CIN exhibited antimicrobial activity through a reduction in diet digestibility and total VFA concentration. Conversely, there were no effects of CIN on concentration of total VFA and diet fermentability in the DF. The addition of CIN altered $\mathrm{N}$ metabolism in the Rusitec, decreasing $\mathrm{N}$ disappearance, $\mathrm{NH}_{3}-\mathrm{N}$ concentration, and the molar proportions of BCVFA. Contrarily, no effect of CIN in the $\mathrm{DF}$ was observed on $\mathrm{N}$ degradation, $\mathrm{NH}_{3}-$ $\mathrm{N}$ concentration, and the molar proportions of BCVFA. In the Rusitec, CIN increased ${ }^{15} \mathrm{~N}$ enrichment in bacterial fractions, but had no effect on the production of microbial $\mathrm{N}$, whereas in the $\mathrm{DF}$, microbial $\mathrm{N}$ flow and efficiency of microbial protein synthesis were decreased by CIN addition. Discrepancies in the effects of CIN between the $2 \mathrm{CC}$ systems may be due to the higher dilution rate and consequently the lower effective CIN concentration in the DF than in the Rusitec.

Results from this study show that CIN exhibited antimicrobial activities in both CC systems, but the effects were more pronounced with the Rusitec than with the DF. However, because reductions in total VFA concentration, diet fermentability, and efficiency of microbial protein synthesis are nutritionally unfavorable consequences, supplementation with CIN at the dosage evaluated may have adverse effects on the metabolism and productivity of ruminants.

\section{ACKNOWLEDGMENTS}

This project was financially supported by the Dairy Farmers of Canada (Ottawa, ON) and Agriculture and Agri-Food Canada (Matching Investment Initiative). The authors are grateful to S. Methot (Dairy and Swine Research and Development Centre, Sherbrooke, QC, Canada) for his help with statistics. Thanks to C. Kamel from Pancosma S. A. (Bellegarde-sur-Valserine, France) for providing the cinnamon leaf oil.

\section{REFERENCES}

Acamovic, T., and J. D. Brooker. 2005. Biochemistry of plant secondary metabolites and their effects in animals. Proc. Nutr. Soc. 64:403-412.

AOAC. 1990. Official Methods of Analysis. Vol. I. 15th ed. Association of Official Analytical Chemists, Arlington, VA.

Beauchemin, K. A. 2002. Applying Nutritional Management to Rumen Health. http://www.das.psu.edu/dairynutrition/documents/beau chemin.pdf Accessed Apr. 10, 2005.

Benchaar, C., H. V. Petit, R. Berthiaume, D. R. Ouellet, J. Chiquette, and P. Y. Chouinard. 2007. Effects of essential oils on digestion, ruminal fermentation, rumen microbial populations, milk production, and milk composition in dairy cows fed alfalfa silage or corn silage. J. Dairy Sci. 90:886-897.

Benchaar, C., H. V. Petit, R. Berthiaume, T. D. Whyte, and P. Y. Chouinard. 2006. Effects of addition of essential oils and monensin premix on digestion, ruminal fermentation, milk production and milk composition in dairy cows. J. Dairy Sci. 89:4352-4364.

Broderick, G. A., and J. H. Kang. 1980. Automated simultaneous determination of ammonia and total amino acids in ruminal fluid and in vitro media. J. Dairy Sci. 63:64-75.

Busquet, M., S. Calsamiglia, A. Ferret, P. W. Cardozo, and C. Kamel. 2005a. Effects of cinnamaldehyde and garlic oil on rumen microbial fermentation in a dual-flow continuous culture. J. Dairy Sci. 88:2508-2516.

Busquet, M., S. Calsamiglia, A. Ferret, M. D. Carro, and C. Kamel. 2005b. Effect of garlic oil and four of its compounds on rumen microbial fermentation. J. Dairy Sci. 88:4393-4404.

Busquet, M., S. Calsamiglia, A. Ferret, and C. Kamel. 2005c. Screening for the effects of natural plant extracts and secondary plant metabolites on rumen microbial fermentation in continuous culture. Anim. Feed Sci. Technol. 123:597-613.

Busquet, M., S. Calsamiglia, A. Ferret, and C. Kamel. 2006. Plant extracts affect in vitro rumen microbial fermentation. J. Dairy Sci. 89:761-771.

Castillejos, L., S. Calsamiglia, and A. Ferret. 2006. Effect of essential oil active compounds on rumen microbial fermentation and nutrient flow in in vitro systems. J. Dairy Sci. 89:2649-2658.

CCAC. 1993. Guide to the Care and Use of Experimental Animals. Vol. 1. E. D. Olfert, B. M Cross, and A. A. McWilliam, ed. Canadian Council on Animal Care, Ottawa, Ontario, Canada.

Cardozo, P. W., S. Calsamiglia, A. Ferret, and C. Kamel. 2004. Effects of natural plant extracts on ruminal protein degradation and fermentation profiles in continuous culture. J. Anim. Sci. 82:32303236.

Czerkawski, J. W., and G. Breckenridge. 1977. Design and development of a long term rumen simulation technique (RUSITEC). Br. J. Nutr. 38:371-384. 
Dorman, D. H., and S. G. Deans. 2000. Antimicrobial agents from plants: Antibacterial activity of plant volatile oils. J. Appl. Microbiol. 88:308-316.

Evans, J. D., and S. A. Martin. 2000. Effects of thymol on ruminal microorganisms. Curr. Microbiol. 41:336-340.

Greathead, H. 2003. Plants and plant extracts for improving animal productivity. Proc. Nutr. Soc. 62:279-290.

Helander, I. M., H. L. Alakomi, K. Latva-Kala, T. Mattila-Sandholm, I. Pol, E. J. Smid, L. G. M. Gorris, and A. von Wright. 1998. Characterization of the action of selected essential oil components on gram-negative bacteria. J. Agric. Food Chem. 46:3590-3595.

Hoover, W. H., B. A. Crooker, and C. J. Sniffen. 1976. Effects of differential solid-liquid removal rates on protozoa numbers in continuous cultures of rumen contents. J. Anim. Sci. 43:528-534.

Ivan, M., L. Neill, R. Forster, R. Alimon, L. M. Rode, and T. Entz. 2000. Effects of isotricha, dasytricha, entodinium, and total fauna on ruminal fermentation and duodenal flow in wethers fed different diets. J. Dairy Sci. 83:776-787.

Kim, J., M. R. Marshall, and C.-I. Wei. 1995. Antibacterial activity of some essential oil compounds against five foodborne pathogens. J. Agric. Food Chem. 43:2839-2845.

Klieve, A. V., and R. S. Hegarty. 1999. Opportunities for biological control of ruminal methanogenesis. Aust. J. Agric. Res. 50:1315-1319.

Lambert, R. J. W., P. N. Skandamis, P. Coote, and G.-J. E. Nychas. 2001. A study of the minimum inhibitory concentration and mode of action of oregano essential oil, thymol and carvacrol. J. Appl. Microbiol. 91:453-462.

Lee, S. S., J. K. Ha, and K. J. Cheng. 2000. Relative contributions of bacteria, protozoa and fungi to in vitro degradation of orchard grass cell walls and their interactions. Appl. Environ. Microbiol. 66:3807-3813.

McAllister, T. A., H. D. Bae, G. A. Jones, and K. J. Cheng. 1994. Microbial attachment and feed digestion in the rumen. J. Anim. Sci. 72:3004-3018.

McDougall, E. I. 1948. Studies on ruminant saliva 1. The composition and output of sheeps saliva. Biochem. J. 43:99-109.

Miller, T. L., and S. E. Jenesel. 1979. Enzymology of butyrate formation by Butyrivibrio fibrisolvens. J. Bacteriol. 138:99-104.

Moss, A. R., J. P. Jouany, and J. Newbold. 2000. Methane production by ruminants: Its contribution to global warming. Ann. Zootech. 49:231-253.
Newbold, C. J., F. M. McIntosh, P. Williams, R. Losa, and R. J. Wallace. 2004. Effects of a specific blend of essential oil compounds on rumen fermentation. Anim. Feed Sci. Technol. 114:105-112.

Ogimoto, K., and S. Imai. 1981. Atlas of Rumen Microbiology. Japan Scientific Societies Press, Tokyo.

Russell, J. B. 2002. Rumen Microbiology and Its Role in Ruminant Nutrition. James B. Russell Publishing Co., Ithaca, NY.

Russell, J. B., and H. J. Strobel. 1989. Effect of ionophores on ruminal fermentation. Minireview. Appl. Environ. Microbiol. 55:1-6.

SAS Institute. 2000. SAS/STAT User's Guide. Release 8.02. SAS Inst. Inc., Cary, NC.

Stewart, C. S. 1991. The rumen bacteria. Pages 15-26 in Rumen Microbial Metabolism and Ruminant Digestion. J. P. Jouany, ed. INRA Editions, Paris, France.

Ultee, A., E. P. W. Kets, and E. J. Smid. 1999. Mechanisms of action of carvacrol on the food-borne pathogen Bacillus cereus. Appl. Environ. Microbiol. 65:4606-4610.

Van Soest, P. J. 1982. Nutritional Ecology of the Ruminant. Cornell University Press, Ithaca, NY.

Van Soest, P. J., J. B. Robertson, and B. A. Lewis. 1991. Symposium: Carbohydrate methodology, metabolism and nutritional implications in dairy cattle. Methods for dietary fiber, neutral detergent fiber, and nonstarch polysaccharides in relation to animal nutrition. J. Dairy Sci. 74:3583-3597.

Vázquez-Añón, M., T. Cassidy, P. McCullogh, and G. A. Varga. 2001. Effects of Alimet on nutrient digestibility, bacterial protein synthesis and ruminal disappearance during continuous culture. J. Dairy Sci. 84:159-166.

Walsh, S. E., J. Y. Maillard, A. D. Russell, C. E. Catrenich, D. L. Charbonneau, and R. G. Bartolo. 2003. Activity and mechanisms of action of selected biocidal agents on gram-positive and -negative bacteria. J. Appl. Microbiol. 94:240-427.

Wang, Y., T. A. McAllister, L. M. Rode, K. A. Beauchemin, D. P. Morgavi, V. L. Nsereko, A. D. Iwaasa, and W. Yang. 2001. Effects of an exogenous enzyme preparation on microbial protein synthesis, enzyme activity and attachment to feed in the rumen simulation technique (Rusitec). Br. J. Nutr. 85:325-332.

Wang, Y., T. A. McAllister, L. J. Yanke, Z. J. Xu, P. R. Cheeke, and K. J. Cheng. 2000. In vitro effects of steroidal saponins from Yucca schidigera extract on rumen microbial protein synthesis and ruminal fermentation. J. Sci. Food Agric. 80:2114-2122. 